\title{
Perumusan Strategi Business Model Canvas Untuk Pengembangan Usaha Industri Fotografi: Studi Kasus Exstudio, Pekanbaru
}

\author{
Khendy Chan ${ }^{1)}$, Christy Dwita Mariana ${ }^{2)}$, Dionisius Yusuf ${ }^{4)}$ \\ Universitas Agung Podomoro, ${ }^{1,2}$ \\ Institut Shanti Bhuana ${ }^{3)}$ \\ christy.mariana@podomorouniversity.ac.id \\ dionisius.yusuf@shantibhuana.ac.id
}

Received: 31 Maret 2021; Accepted: 04 April 2021; Published: 30 April 2021

\begin{abstract}
The aim of the study is to determine the strategies that can be used by Exstudio. The research method used descriptive using interview, observation, reference and documentation. Data analysis was carried out descriptively using canvas models and SWOT analysis. The results of the study showed Exstudio has a segmentation of the open market consumer segment, the consumer market (B2C) and government market. The proposition of value of Exstudio is to offer exclusive services to its clients following current trends. The channels of Exstudio's business are digital-based channels with the use of social media. Exstudio provides both prepurchase and post-order photography and videography services. Income derived from documentation services and commission for printing orders. Exstudio resources consist of: (1) physical resources (office); (2) Human resources (core management and freelance employees); (3) Financial resources (personal capital and grant funds); and (4) Intellectual resources (brands, knowledge, partnerships, databases). Exstudio relies on its main activities namely, production, distribution, marketing and administration. Exstudio's main partners consist of event organizers and wedding organizers, printing vendors, suppliers of packaging material supplies. Exstudio is a value-driven type and consists of fixed costs and variable costs that are used for production, marketing, and administration.
\end{abstract}

Keywords: Business Model Canvas, Exstudio, SWOT, Strategies, Preposition

\section{PENDAHULUAN}

Inovasi dalam dunia fotografi terus berkembang seiring dengan perubahan jaman. Saat ini fogorgrafi merupakan salah satu industri yang banyak digeluti oleh masyarakat terutama para generasi muda. Penggunaan fotografi sangat luas, mulai dari penggunaan untuk pribadi hingga pada tingkat negara.

Fotografi juga berperan sebuah aliran seni kreatif dalam berbagai golongan dari hobi individu hingga seniman fotografi profesional. Di sisi lain, kini peran fotografi juga sudah mulai bergeser menjadi kebutuhan utama dalam relasi sosial di masyarakat. Media sosial yang banyak dipergunakan oleh generasi mileneal banyak menggunakan fotografi yang ditujukan untuk menjalin relasi sosial. Maka tidak mengherankan bila industri fotografi tumbuh dengan sangat pesat di tanah air. Pertumbuhan industri fotografi sangat masif dengan berbagai sub industri dan golongan.

Dinamika dalam industri fotografi sangat tinggi terutama dalam hal penggunaan teknologi. Sebagai contoh penggunaan kamera analog dan digital yang berubah sedemikian cepat seiring dengan perkembangan teknologi dalam industri fotografi. Dengan perkembangan dan peralihan teknologi yang berjalan terus, industri fotografi semakin dilirik sebagai ladang yang berpotensi unttk menghasilkan pendapatan. Hal ini tentunya mendorong banyak wirausaha muda untuk membuka usaha industri fotografi baik usaha perorangan hingga usaha berskala besar. Pertumbuhan industri fotografi juga berdampak positif terhadap konsumen. Hal ini dikarenakan konsumen memiliki 
banyak pilihan dan ragam jasa dalam fotografi.

Berdasarkan data dari Badan Ekonomi Kreatif (2018), bisnis fotografi mengalami peningkatan setiap tahunnya diiringi dengan peningkatan penggunaan media visual fotografi. Pada tahun 2015 - 2016, bisnis fotografi yang beroperasi di tanah air berjumlah 5.024 unit. Pertumbuhan industri fotografi juga dirasakan di provinsi Riau. Saat ini, Riau merupakan salah satu tempat menggiurkan buat industri fotografi. Hal ini mengingat pesatnya pembangunan berbagai fasilitas yang sedang berlangsung di Riau. Selain itu, pertumbuhan populasi kaum muda di daerah ini juga mendorong peningkatan industri fotografi.

Meskipun demikian, industri fotogragfi di Riau menghadapi berbagai masalah yang dapat menghambat pertumbuhan industri fotografi. Minimnya kegiatan pameran fotografi, belum tersedianya wadah buat komunitas pencinta fotografi yang dapat menampung ide-ide kreatif anak muda di Riau serta minimnya lokasi outdoor untuk pemotretan adalah segelintir persoalan yang dihadapi para insan industri fotografi di Riau, khususnya di kota Pekanbaru.

Hambatan-hambatan yang dijabarkan diatas merupakan salah satu penghambat buat perkembangan bisnis fotografi di Pekanbaru. Untuk mengatasi hambatan tersebut, maka diperlukan inovasi dan konsep terkini untuk dapat memecahkan permasalahan yang ada. Exstudio sebagai salah satu pioner dunia fotografi yang berlokasi di Pekanbaru tidak terlepas dari permasalahan tersebut dalam pengembangan usaha bisninya.

Exstudio yang bergerak dalam bidang private party modern berbagai permasalahan diatas turut mempengaruhi keberlangsungan bisnis secara signifikan. Exstudio dituntut untuk terus berinovasi dan mengikuti perkembangan tren dunia fotografi. Oleh karena itu diperlukan adanya strategi untuk mengatasi permasalahan yang sedang dihadapi. Penggunaan model bisnis kanvas merupakan salah satu cara yang dilakukan pihak Exstudio untuk mendapatkan strategi bisnis yang tepat untuk mengembangkan bisnis Exstudio.

Osterwalder \& Pigneur (2017) mengungkapkan bahwa business model canvas (BMC) adalah alat yang dapat digunakan dalam menerapkan berbagai bentuk kontrol dan pengawasan terhadap suatu bisnis yang berjalan sehingga memberikan pelaku usaha suatu pemahaman terhadap bisnis yang dijalankan. Lebih lanjut Osterwalder dan Pigneur menjelaskan bahwa model bisnis kanvas merupakan model bisnis yang memberikan pokok-pok $\phi k$ landasan bagi pelaku usaha atau penyusun strategi menyalurkan sebuah gagasan nilai yang ditanamkan dalam perusahaan.

BMC dapat digunakan secara sistematis untuk memahami, mendesain dan menerapkan model bisnis yang sudah ada atau membuat model bisnis yang baru. BMC meliputi sembilan elemen berbeda yang saling terkait dan teridentifikasi sebagai kunci penting untuk menciptakan model bisnis yang sukses. Sembilan elemen tersebut meliputi Customer Segments, Value Proposition, Channels, Customer Relationships, Revenue Streams, Key Resources, Key Activities, Key Partners, dan Cost Structure.

BMC merupakan metode yang tepat untuk merumuskan strategi pada bisnis Exstudio karena dengan model BMC perusahaan dapat mengetahui bagaimana setiap aspek dalam bisnisnya berhubugan satu dengan lainnya. Kemudian melalui analisa terhadap masing-masing hubungan tersebut diharapkan dapat menciptakan nilai yang lebih baik dari pada sebelumnya melalui keputusan strategis.

Pemaparan permasalahan yang diuraikan di atas dapat menggunakan konsep BMC untuk merumuskan strategi bisnis Exstudio yang dapat digunakan sebagai dasar untuk menentukan strategi atau langkah apa yang akan diambil untuk meningkatkan nilai yang dimiliki Exstudio.

Pada prosesnya model bisnis kavas diibantu dengan analisis SWOT dalam proses perencanaan strategis dalam menciptakan konsep bisnis yang lebih maju dalam menghadapi perubahan kondisi pasar. Analisis SWOT merupakan alat nalisis yang 
digunakan untuk menilai kekuatan, kelemahan, peluang dan ancaman suatu organisasi. Analisis SWOT memberikan empat presfektif dalam evaluasi blok bangunan model bisnis sehingga memberikan dasar uyang baik untuk pengambilan keputusan dan inovasi disekitar model bisnis (Oswalder dan Pigneur, 2017).

\section{METODE PENELITIAN}

Penelitian ini menggunakan desain penelitian deskriptif kualitatif yang dilakukan dengan teknis studi kasus. Menurut Sugiyono (2012), metode penelitian kualitatif melihat hubungan antar-variabel pada objek yang diteliti lebih bersifat interaktif yang digunakan untuk menggambarkan atau menganalisis suatu hasil penelitian namun tidak membuat kesimpulan yang lebih luas.

Mukhtar (2013) menjabarkan bahwa penelitian deskriptif adalah penelitian yang berusaha mendeskripsikan seluruh gejala atau keadaan yang ada, yaitu keadaan gejala menurut apa adanya pada saat penelitian dilakukan. Studi kasus dalam penelitian deskriptif berusaha menggambarkan kehidupan dan tindakan-tindakan individu, satu kelompok, satu organisasi, satu program kegiatan, dan sebagainya secara khusus pada lokasi tertentu dengan kasus tertentu untuk memperoleh deskripsi yang utuh dan mendalam dari sebuah entitas.

Penelitian dilakukan di Exstudio yang berlokasi di Kota Pekanbaru, Riau. Usaha bisnis ini dipilih sebagai secara sengaja (purposive) dengan alasan bahwa studio foto ini adalah salah satu pioneer dan trendsetter dunia fotografi di Kota Pekanbaru. Namun saat ini, perusahaan ini mengalami berbagai permasalahan dengan tingkat pendapatan yang stagnasi bahkan cenderung menurun.

Teknis pengumpulan data yang dilakukan dalam penelitian ini adalah melalui observasi partisipatif, wawancara, dokumentasi dan studi literatur. Analisis data dilakukan melalui reduksi data, penyajian data dan penarikan kesimpulan. Model bisnias Exstudio dianalisis megunakan busines model canvas melalui teknis desain bisnis. Terdapat enam teknis desain bisnis diantaranya wawasan konsumen, pembentukan ide, berpikir visual, ptototyping, bercerita dan skenario (Suwandiman, 2017).

\section{HASIL DAN PEMBAHASAN Gambaran Umum Usaha Exstudio}

Exstudio berdiri pada bulan November 2017. Usaha ini berlokasi di Jalan Tamtama, Kelurahan Labuh Baru Timur, Kecamatan Payung Sekaki, kota Pekanbaru, Riau yang merupakan salah satu lokasi strategis di kota Pekanbaru. Exstudio bergerak di bidang penyedia jasa fotografi dan videografi milenial, seperti acara private party dan modern sweet seventeen. Sebagai usaha rintisan, Exstudio masih belum memiliki badan usaha.

Dalam menjalankan bisnisnya Exstudio memiliki visi yaitu menjad pemain ternama dalam industri kreatif dengan memberikan pengalaman terbaik bagi masyarakat Indonesia. Sedangkan misi Exstudio adalah menciptakan pengalaman dan momen yang berkesan dan eksklusif dengan mengutamakan pelayanan dan inovas kreatif kepada para pelanggan. Adapun tujuan Exstudio adalah mencar keuntungan melalui pengembangan bisnis Exstudio melalui pengembangan usaha fotografi dan videografi. membangun studio yang mampu menunjang industri seni fotografi dan videografi di kota Pekanbaru, dan membangun jaringan bisnis dengan mitra yang memiliki industri yang berkaitan dengan bisnis Exstudio.

\section{Analisis Business Model Canvas (BMC) Exstudio}

Peta business model canvas (BMC) berguna untuk mempermudah pemilik usaha Exstudio dalam memahami model bisnis yang sedang dijalankannya serta dapat memahami pendapat konsumen mengenai jasa fotografi dan videografi yang ditawarkan Exstudio. Terdapat sembilan blok dalam business model canvas yang tergambar dalam usaha fotografi Exstudio. Pada blok segmentasi konsumen, hubungan pelanggan, arus pendapatan, sumber daya utama, kemitraan utama, struktur biaya, didapatkan melalui metode wawancara. Sedangkan pada blok lainnya didapatkan melalui metode observasi. 
Segmentasi konsumen Exstudio adalah konsumen dari kalangan menengah hingga menengah atas yang membutuhkan jasa fotografi. Konsumen Exstudio tidak hnya berasal dari kota Pekanbaru melainkan juga berasal dari kota lain di sekitar Pekanbaru, seperti Dumai, Taluk Kuantan. Bahkan konsumen dari Jakarta pun pernah menggunakan jasa Exstudio.

Menurut Amstring dan Kotler (1999) terdapat lima jenis pasar pelanggan, yaitu pasar konsumen (business to consumer), pasar industri, pasar penjual kembali (business to busines), pasar pemerintah,dan pasar internasional. Mengacu pada lima jenis pasar pelanggan yang dipaparkan oleh Kotler, Exstudio memiliki 2 jenis pasar pelanggan yaitu pasar konsumen (business to consumer/B2C) dan pasar pemerintah. Namun demikian sekitar 90\% konsumen Exstudio adalah pasar konsumen, sisanya adalah pasar pemerintah.

\section{Value Propositions}

Proposisi nilai merupakan nilai tambah yang diberikan oleh perusahaan kepada akonsumen. Hal inilah ysng menjadi alasan pelanggan lebih memilih suatu perusahaan daripada perusahaan lain.

Dalam menjalankan bisnisnya, exstudio mengutamakan pelayanan eksklusif kepada klien dengan mengikuti tren masa kini. Selain itu, Exstudio senantiasa melakukan inovasi dalam rangka memaksimalkan pelayanan kepada konsumen. Dengan proposisi nilai yang dimiliki Exstudio berharap dapat memenangkan persaingan dalam dunia fotografi di kota Pekanbaru.

\section{Channels}

Channels adalah saluran yang digunakan perusahaan untuk mendistribusikan atau memasarkan produknya kepada konsumen. Channel utama yang digunakan Exstudio adalah berbasis digital dengan penggunaan media sosial, seperti Instagram. Penggunaan social media dikarenakan pasar sasaran Exstudio adalah mereka yang memang senantiasa menggunakan social media dalam kehidupan sehariharinya. Channel lain yang digunakan oleh Exstudio adalah kontak langsung dengan konsumen yang lagi membutuhkan jasa fotografi. Selain cara diatas, Exstudio juga menggunakan pameran dan bazar lokal untuk menambah jangkauan pasar. Dalam kegiatan tersebut, Exstudio membuka photobooth sebagai media pemasaran. Kerja sama dengan vendor dan event organizer juga dilakukan Exstudio untuk meningkatkan pangsa pasar mereka.

\section{Customer Relationships}

Customer relationship menggambarkan hubungan yang dibangun antara Exstudio dengan pelanggan. Customer relationships yang dilakukan Exstudio saat ini adalah memberikan pelayanan baik pra pembelian maupun pasca pemesanan jasa fotografi dan videografi. Pelayanan yang diberikan didasari pada aspek kenyamanan pada klien ketika mereka menggunakan jasa Exstudio. Untuk itu, Exstudio memberikan bekal kemampuan public speaking sebagai salah satu softskill buat para fotografer atau videographer yang bekerja di Exstudio.

Sebelum mengerjakan pekerjaan yang diberikan oleh konsumen, terlebih dahulu Exstudio melakukan kegiatan meeting dengan klien yang bertujuan untuk membina hubungan baik dengan klien. Dalam pertemuan Exstudio akan memperkenalkan anggota tim yang akan melakukan proses dokumentasi dan membahas berbagai konsep dokumentasi yang diinginkan oleh klien. Exstudio juga menawarkan konsep dokumentasi. Selain itu, dalam rangka menjaga hubungan dengan klien, Exstudio juga aktif berinteraksi dengan klien dengan cara menjawab setiap pertanyaan dan keluhan dari klien.

\section{Revenue Streams}

Revenue streams Exstudio berasal dari jasa dokumentasi baik itu fotografi maupun videografi. Selain itu, Exstudio juga memperoleh revenue streams dari komisi pesanan percetakan yang dipesan konsumen melalui Exstudio. Saat ini, sistem administrasi keuangan Exstudio masih dilakukan dengan cara sederhana, yaitu hanya melakukan pencatatan neraca laba dan rugi saja. 


\section{Key Resources}

Sumber daya utama menggambarkan aset-aset terpenting yang diperlukan agar sebuah model bisnis dapat berfungsi. Menurut Osterwalder \& Pigneur (2017), sumber daya ini memungkinkan perusahaan menciptakan dan menawarkan value proposition, menjangkau pasar, mempertahankan hubungan dengan customer segments, dan memperoleh pendapatan. Terdapat empat sumber daya utama perusahaan yaitu fisik, SDM, finansial dan intelektual.

Sumber daya fisik yaitu bangunan fisik berupa ruko yang digunakan sebagai kantor Exstudio. Sumber daya manusia yang dimiliki oleh Exstudio adalah 3 orang pegawai dan pengurus inti. Jika dalam kondisi permintaan yang cukup tinggi dari para klien, Exstudio merektrut tenaga eksternal sebagai anggota kru freelance untuk menyelesaikan pekerjaan yang diperoleh dari klien. Sumberdaya finansial berupa modal awal dan modal operasional.

Sumber daya kunci intelektual Exstudio meliputi brand image yang sudah merekat di benak konsumen, pengetahuan tentang dunia fotografi dan videografi, partnerships, dan database konsumen yang merupakan komponen yang penting dalam membuat model bisnis yang kuat.

\section{Key Activities}

Key activities merupakan kegiatan utama yang dilakukan organisasi atau perusahaan agar menghasilkan nilai tambah dengan baik (Osterwalder \& Pigneur, 2017). Setiap model bisnis memiliki aktivitas-aktivitas utama. Aktivitas utama Exstudio termasuk ke dalam kategori operasi produksi (production) berupa aktifitas produksi, distribusi, pemasaran, dan administrasi.

Aktivitas pemasaran yang dilakukan oleh Exstudio adalah melalui sosial media dan word-of-mouth marketing. Aktivitas administrasi meliputi pembukuan dan pencatatan segala macam transaksi selama kegiatan usaha yang dilakukan secara manual pada buku jurnal.

\section{Key Partnerships}

Key partnerships merupakan mitra utama dalam bisnis seperti supplier, sehingga model bisnis dapat bekerja. Menurut Osterwalder \& Pigneur (2017), perusahaan menjalin kerjasama untuk beberapa alasan dan jalinan kerjasama menjadi landasan dari beberapa model bisnis. Perusahaan membuat aliansi untuk mengoptimasi model bisnisnya, mengurangi risik $\phi$, atau memperoleh sumber daya.

Dalam menjalankan bisnisnya, Exstudio menjalin kerjasama dengan beberapa event organizer dan wedding organizer, vendor percetakan, pemasok persediaan material kemasan. Exstudio juga mengikuti kegiatan pameran dan bazar di kota Pekanbaru sebagai wadah untuk memasarkan jasa fotografi dan videografi yang dimiliki oleh Exstudiф.

\section{Cost Structure}

Struktur biaya menggambarkan keseluruhan biaya yang digunakan untuk mengoperasikan model bisnis yang dijalankan oleh Exstudio. Cost structure Exstudio terdiri dari biaya tetap dan biaya tidak tetap. Biaya tetap Exstudio terdiri dari biaya sewa bangunan, biaya keamanan dan kebersihan lingkungan, biaya gaji karyawan, dan biaya listrik. Keseluruhan biaya tetap ini merupakan biaya operasional dan produksi yang dikeluarkan oleh Exstudio dalam menjalankan roda bisnisnya. Sedangkan biaya tidak tetap yang dikeluarkan oleh Exstudio berupa biaya gaji kru tambahan freelance, biaya pengiriman kurir, biaya perlengkapan dalam dokumentasi acara, dan biaya perlengkapan alat tulis kantor.

Pada dasarnya Exstudio belum memiliki model bisnis yang tepat. Exstudio masih menggunakan manajemen usaha secara tradisional. Terbatasnya inovasi jasa fotografi dan videografi juga menghambat pertumbuhan usaha Exstudio. Perusahaan juga belum melakukan promosi secara gencar sehingga daerah pemasaran masih terbatas hanya di sekitar kota Pekanbaru.

\section{Strategi Pengembangan Bisnis Exstudio}

Pengembangan adalah suatu proses untuk mengubah kondisi yang belum atau kurang baik menjadi lebih baik di dalam rangka mencapai tujuan tertentu. Menurut Rangkuti (2006), strategi merupakan alat untuk mencapai tujuan. 
Strategi merupakan tindakan yang bersifat incremental (senantiasa meningkat) dan terus menerus, serta dilakukan berdasarkan sudut pandang tentang apa yang diharapkan oleh para pelanggan di masa depan.

Setelah dilakukan pemetaan model bisnis kanvas pada usaha Exstudio tahap berikutnya dilakukan evaluasi model bisnis dengan menggunakan analisis SWOT pada setiap blok elemen dalam kanvas model bisnis. Pada dasarnya terdapat empat isu strategis dari kesembilan blok elemen tersebut yaitu proposisi nilai (value proposition), strutktur biaya (revenue stream dan cost structure) infrasturktur (key activities, key recources dan key partnership) dan hubungan pelangan (customer segments, channels dan custumer realationship).

Berdasarkan hasil analisis SWOT pada kesembilan eleman kanvas model bisnis, diperoleh empat strategi yang dapat diterapkan oleh Exstudio yaitu strategi S-O, S-T, W-O dan W-T. Strategi S-O yang dapat diterapkan di Exstudio adalah diversifikasi usaha dan peningkatan hubungan baik dengan pelanggan, meningkatkan kualitas konten fotografi dan videografi dengan memanfaatkan kemajuan teknologi fotografi, membangun studio fotografi dan videografi, memperluas jangkauan kerjasama dengan pihak eksternal, dan meningkatan keahlian anggota tim seeara konsisten dan berkesinambungan.

Strategi S-T yang dapat dipergunakan oleh Exstudio adalah melanjutkan pencarian investor potensial untuk membantu pengembangan usaha Exstudio, meningkatkan kualitas pelayanan terhadap para klien, dan melakukan peningkatan kerja yang semakin profesional dalam industri fotografi.

Adapun strategi W-O yang direkomendasikan untuk Exstudio adalah meningkatkan bisnis usaha fotografi dan vidografi melalui penetrasi pasar, membangun website perusahaan, memfokuskan pemasaran secara digital dan menggunakan jaringan (networking) untuk memperluas pangsa pasar di kota Pekanbaru dan sekitarnya.

Sedangkan strategi W-T yang disarankan adalah menjalin kerja sama yang lebih baik dengan komunitas freelancer di kota Pekanbaru, membangun fasilitas fotografi dan videografi dan membangun sistem perusahaan yang lebih solid.

Selanjutnya terdapat dua alternatif model bisnis baru yang dapat diterapkan Exstudio di masa mendatang, yaitu:

1. Exstudio fokus pada penetrasi pasar untuk meningkatkan pemasaran fotografi dan videografi perusahaan. Strategi penetrasi pasar yaitu usaha untuk meningkatkan pangsa pasar untuk produk/jasa saat ini melalui upaya pemasaran yang lebih besar. Exstudio dapat melakukan promosi penjualan yang ekstensif melalui publikasi dan pemasaran online diberbagai platform sosial media seperti Instagram, twitter, tiktok, dan facebook. Selain itu, Exstudio dapat memanfaatkan networking untuk mendapatkan konsumen dengan mengikuti berbagai kegiatan pameran dan acara (event) tertentu. Strategi penetrasi pasar dapat dilakukan apabila Exstudio apabila sudah memiliki studio fotografi dan vidoegrafi sendiri dengan peralatan dan fasilitas yang lengkah sehingga dapat memenuhi permintaan konsumen atau klien.

2. Model bisnis kedua yang dapat dilakukan Exstudio adalah fokus menawarkan value baru melalui pengembangan produk dan peningkatan hubungan baik dengan pelanggan. Strategi pengembangan produk adalah strategi yang mencari peningkatan penjualan dengan memperbaiki atau memodifikasi produk/jasa saat ini. Strategi pengembangan produk yang dapat dilakukan oleh Exstudio adalah melakukan diversifikasi produk fotografi dan videografi misalnya menjual produk kamera dan studio foto mini portable. Konsultasi penggunaan produk untuk memperoleh foto terbaik, adanya garansi produk serta layanan perbaikan dan penggantian spare part dapat dilakukan Exstudio ketika melakukan diversifikasi usaha.

\section{KESIMPULAN}

Berdasarkan analisis model bisnis kanvas Exstudio, maka dapat diperoleh kesimpulan sebagai berikut: 
a. Segmen pelanggan: Exstudio fokus pada dua segmen pelanggan, yaitu $90 \%$ pangsa pasar konsumen (Business to Consumer/B2C) dan sisanya pasar pemerintah.

b. Proposisi nilai: Usaha Exstudio menawarkan pelayanan eksklusif kepada klien dengan mengikuti tren masa kini.

c. Channels: Saluran yang digunakan untuk memasarkan bisnis Exstudio adalah saluran berbasis digital dengan penggunaan media sosial, seperti Instagram.

d. Hubungan pelanggan : Exstudio memberikan pelayanan baik pra pembelian maupun pasca pemesanan jasa fotografi dan videografi.

e. Arus pendapatan: Pendapatan diperoleh dari jasa dokumentasi baik itu fotografi maupun videografi. Selain itu, Exstudio juga memperoleh revenue streams dari komisi pesanan percetakan yang dipesan konsumen melalui Exstudio

f. Sumber daya utama: Sumber daya perusahaan terdiri atas: (1) Sumber daya fisik (kantor); (2) Sumber daya manusia (pengurus inti dan pegawai freelance); (3) Sumber daya finansial (modal pribadi dan dana investor); dan (4) Sumber daya intelektual (merek, pengetahuan, partnerships, database).

g. Aktivitas utama : Exstudio mengandalkan aktivitas utama yaitu, produksi, distribusi, pemasaran dan administrasi.

h. Kemitraaan utama : Mitra utama Exstudio terdiri dari event organizer dan wedding organizer, vendor percetakan, pemasok persediaan material kemasan.

i. Struktur biaya : Exstudio merupakan jenis value-driven, dan terdiri dari biaya tetap dan biaya variabel yang digunakan untuk produksi, pemasaran, dan administrasi.

2. Berdasarkan analisis SWOT yang dilakukan maka terdapat empat alternatif strategi yang bisa diterapkan oleh Exstudio dan setelah digabungkan dengan sembilan element blok menunjukkan bahwa terdapat dua strategi utama model bisnis yang dapat diterapkan oleh Exstudio yaitu fokus meningkatkan bisnis usaha fotografi dan vidografi melalui penetrasi pasar (strategi W-O) dan fokus pada penawaran value baru melalui diversifikasi usaha dan peningkatan hubungan baik dengan pelanggan (strategi S-O).

\section{REFERENSI}

Amstrong dan Kotler, P (1999). Prinsip-Prinsip Pemasaran, Edisi Delapan, Jakarta: Penerbit Erlangga.

Badan Ekonomi Kreatif Indonesia (2018): Jumlah Usaha/Perusahdan Ekonomi Kreatif Menurut Subsektor Ekraf Dan Tahun Mulai Beroperasi., http://data.bekraf.go.id/index.php?r $=$ site $\% 2$ Findex, diunduh 26 Juni 2020.

Mukhtar. (2013). Metode Penelitian Deskriptif Kualitatif. Jakarta: GP Press Group.

Osterwalder, A. \& Pigneur, Y. (2017). Business Model Canvas. Jakarta: Elex Media Komputindo.

Rangkuti, F. (2006). Analisis SWOT Teknik Membedah Kasus Bisnis. Jakarta: PT. Gramedia.

Sugiyono. (2012). Metode Penelitian Kuantitatif, Kualitatif, dan $R \& D$. Bandung: Alfabeta.

Suwandiman, K.Z. (2017). Analisis Model Bisnis Kelompok Tani Beras Organik. Suatu Kasus Kelompok Tani Organik Sarinah, Desa Banyuwangi, Ciparay, Kabupaten Bandung, Provinsi Jawa Barat. Skripsi Sarjana Pertanian Jurusan Sosial Ekonomi, Fakultas Pertanian Universitas Padjadjaran.

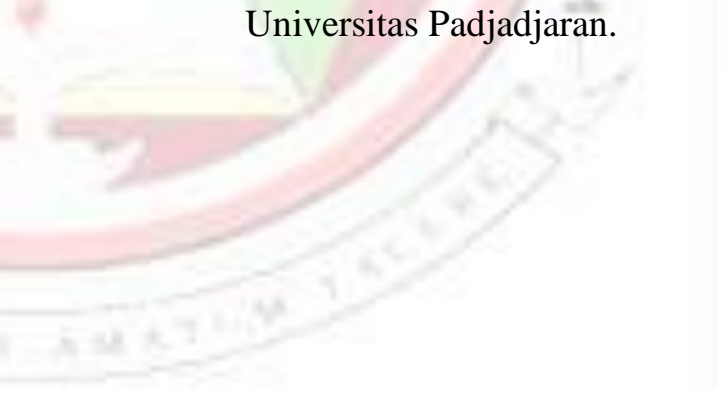

